\title{
RISK FACTORS FOR TUBERCULOSIS AMONG OUT-PATIENTS AT COMMUNITY HEALTH CENTER IN KUDUS, CENTRAL JAVA
}

\author{
Rusnoto \\ School of Health Sciences (STIKES) Muhammadiyah Kudus, Central Java
}

\begin{abstract}
BACKGROUND: According to the World Health Organization, worldwide, 9.6 million people are estimated to have fallen ill with TB in 2014: 5.4 million men, 3.2 million women and 1.0 million children. Globally, $12 \%$ of the 9.6 million new TB cases in 2014 were HIV-positive. This study aimed to estimate the relative risk of tuberculosis with respect to some social-economic factors, in coastal area, Central Java.

SUBJECT AND METHODS: This was a cross sectional study conducted in Kudus, Central Java. A sample of 36 tuberculosis suspects aged >25 years old was selected for this study from visitors at Community Health Centre (Puskesmas) Gribig, Gepok subdistrict, Kudus, Central Java. The dependent variable was Acid Fast Baccilus status. The independent variables included age, nutrition status, education level, employment status, income, and smoking status. Bivariate analysis with Chi Square test was used for data analysis.

RESULTS: The following factors increased the risk of positive test of acid fast baccilus: (1) Productive age $(\mathrm{OR}=25.00 ; 95 \% \mathrm{CI}=3.45$ to 142.86 ; $\mathrm{p}<0.001)$; (2) Body mass index $<25(\mathrm{OR}=5.50 ; 95 \% \mathrm{CI}=1.28$ to 23.69 ; $\mathrm{p}=0.017)$; (3) Education less than high school $(\mathrm{OR}=13.60 ; 95 \% \mathrm{CI}=1.48$ to 125.30; $\mathrm{p}=0.007)$; (4) Employed $(\mathrm{OR}=16.00 ; 95 \% \mathrm{CI}=2.74$ to 93.61; $\mathrm{p}<0.001)$; (5) Income $<\mathrm{Rp} 889.000$ per month $(\mathrm{OR}=26.71 ; 95 \% \mathrm{CI}=2.88$ to 248.00; $\mathrm{p}<0.001)$; (6) Smoker $(\mathrm{OR}=7.00 ; 95 \% \mathrm{CI}=1.59$ to 30.80 ; $\mathrm{p}=0.007)$.

CONCLUSION: Productive age, body mass index <25, education less than high school, employed, income <Rp 889.000 per month, and smoking, are important risk factors for tuberculosis in a coastal area in Central Java, Indonesia.
\end{abstract}

Keywords: tuberculosis, acid fast baccilus, risk factors, coastal area 